\title{
Knowledge, attitude and practice of dentists in Coronavirus disease 2019 pandemic in Turkey
}

\section{Purpose}

The aim was to assess the knowledge, attitudes and anxiety of the dentists in relation to COVID-19.

\section{Materials and Methods}

This cross-sectional survey was conducted amongst 590 dentists employed in Turkey from March to April 2020. The electronic survey consisted of 22 questions related to demographic profile, knowledge, clinical practice and anxiety level of the participants towards dental management of COVID-19. The survey was sent to participants by email and mobile phone messages to be filled electronically.

\section{Results}

Majority of respondents pointed to aerosol (98.5\%), saliva (90.6\%) and mucosal contact (71.4\%) as the transmission routes of COVID-19. Amongst all clinical symptoms of the disease questioned, fever (99.8\%), dry cough (99.1\%), fatigue $(90.0 \%)$ were associated with COVID-19 by vast majority of population. $96.4 \%$ of respondents agreed the usage of gloves as personal protective equipment and it was followed by face shield (88.1\%), disposable gown (83.4\%), protective goggles (73.9\%). Increased usage of FFP2/N95 (33.9\%) and FFP3/N99 (10.9\%) respirators, contrary to reduction of surgical mask usage $(50.7 \%)$, were observed in aerosolgenerating procedures comparing to dental procedures without producing aerosol and these differences were highly significant $(p<0.001, p=0.004, p<0.001)$. The mean anxiety level of respondents was $3.35 \pm 1.18$ (ranging from 0 to 5 ).

\section{Conclusion}

These results demonstrated an adequate knowledge, especially in clinical symptoms of COVID-19 amongst dentists. However, the respirator usage rate in aerosol-generating procedures was not satisfactory which suggesting to necessity of dentists' education about pandemic.

Keywords: COVID-19, Dentistry, Mask, Respirator, Attitude

\section{Introduction}

Several cases with unidentified viral pneumonia was reported in early December in Wuhan, China and was confirmed by the World Health Organization (WHO) on 31 December (1). After analysis of respiratory samples, the causative agent was identified as novel coronavirus (2). On 11 February 2020, WHO and International Committee on Taxonomy of Viruses (ICTV) officially named for the virus as severe acute respiratory syndrome coronavirus 2 (SARS-CoV-2) and the disease as Coronavirus Disease 2019 (COVID-19) respectively (3). According to WHO situation report on 28 April 2020 of COVID-19, it has been documented 2,954,222 cases and 202,597 deaths worldwide and the cases and deaths continue to increase daily (4).

Coronavirus which includes alpha, beta, delta, and gamma subtypes is a single strand RNA virus (5). Severe Acute Respiratory Syndrome coronavirus (SARS-CoV) and Middle East Respiratory Syndrome coronavirus (MERS-

\author{
Berkay Tokuç ${ }^{1}$ D, \\ Fatih Mehmet Coşkunses ${ }^{1}$
}

ORCID IDs of the authors: B.T. 0000-0002-1149-2886; F.M.C. 0000-0001-8764-5992

'Department of Oral and Maxillofacial Surgery, Faculty of Dentistry, Kocaeli University, Turkey

Corresponding Author: Berkay Tokuç E-mail: berkay_tokuc@hotmail.com

Received: 29 April, 2020 Revised: 10 May, 2020 Accepted: 18 May, 2020

DOI: 10.26650/eor.20200049
How to cite: Tokuc B, Coskunses FM. Knowledge, Attitude and Practice of Dentists in Coronavirus Disease 2019 Pandemic in Turkey. Eur Oral Res 2020; 54(2): 86-91. 
CoV) are among the identified types of coronavirus that cause disease in humans. They belong to beta coronavirus subtype and cause respiratory infection similar to SARS-CoV-2 (6).

According to report of WHO-China Joint Mission on COVID-19, the most common symptoms of the disease were fever, cough, fatigue, expectoration, dyspnea and sore throat while nausea, diarrhea and hemoptysis were also reported (7). In addition, Ai et al. (8) claimed most patients (\%90) had bilateral lung involvement in COVID-19 pneumonia and Shi et al. (9) reported the involvement as ground glass opacity, consolidations, air bronchogram and thickening of interlobular septa and adjacent pleura in computed tomography $(C T)$ imaging. Furthermore, patients may experience wide range of complications, including respiratory system and heart injury, impaired renal and liver function and even death (10).

SARS CoV-2 invades the cell through the Angiotensin-converting enzyme 2 (ACE2) cell receptor which were found copiously in respiratory tract (11). Although, its transmission routes are not still completely clear, human to human transmission with contact transmission including oral, nasal and eye mucous membranes and direct transmission via droplets related to respiratory activities was proved (12). Moreover, there are reports about the detection of SARS-CoV-2 in saliva, blood, gastrointestinal tract and urine in the literature $(13,14)$.

Dentists are exposed to pathogenic microorganisms when performing aerosol-generating procedures. The risk of transmission of infectious diseases increases with their close contact with their patients and handling of sharp instruments. Dentists are one of the most vulnerable profession group against COVID-19 because of the inability to take definitive preventive measures during the performing of aerosol-generating procedures and the disease threatens the health of the dental health care workers and patients as well as the community. Thus, dentists should have information about the disease in order to protect their own and patients' health. The objective of this study was to evaluate the knowledge, attitudes and anxiety level of dentists in relation to COVID-19.

\section{Materials and Methods}

This cross-sectional study was conducted from March 2020 to April 2020. The study was approved by Research Ethics Committee of Kocaeli University (Registration number: GOKAEK-2020/5.09 2020/93). The electronic questionnaire which contained about knowledge, attitude and anxiety level of dentists relation to COVID-19 was evolved in Goggle Forms and were sent to participants by e-mail and mobile phone messages.

To be proper for inclusion into the study, the participants had to be dentists who were working in Turkey actively. The questionnaire was developed based on guidelines of American Dental Association (ADA), United Kingdom National Health Service (NHS) and Turkish Dental Association (TDA) about COVID-19.

The questionnaire, containing 22 questions, includes four parts. In the first part, participants were asked about demographic data ( age, sex, year of experience, profession and comorbidities related to COVID-19); in the second, on knowledge about COVID-19 (dental emergency procedures and transmission routes and symptoms of COVID-19); in the third, on attitudes (usage of protective equipments and se- lection of masks or respirators); in the fifth, on anxiety level related to COVID-19.

\section{Statistical analysis}

Data were analyzed statistically with a statistical program (SPSS Statics 26, IBM Inc., Armonk, NY, USA) in the presented study. The standard descriptive methods such as the mean, standard deviation and frequency were applied to determine the characteristics of the sample. Chi-square test and Fischer's exact test were performed to identify the relationship and difference between the mask types used by the participants for the procedures with and without aerosol respectively. For all tests, P-value $<0.05$ was considered statistically significant.

\section{Results}

\section{Demographic data and risk factors}

A total number of 590 participants included in this study. Out of them, 325 were females (55.0\%) and 265 were males (44.9\%). 284 of the participants (48.1\%) were in the age range of 20-30, 166 of them were in the range of 31-40, 87 of them were in the range of 41-50, 49 of them were in the range of 51-60 and 4 of them were over 60 years. 240 of the participants $(40.6 \%)$ had professional experience range of 0-5 years, 120 of them were range of 6-10 years, 74 of them were range of 11-15 years, 55 of them were range of $16-20$ years and 101 of them were range of $21+$.

360 of all participants $(61.0 \%)$ were general dentists, whereas 230 of them (38.9\%) were dental specialists. According to distribution of specialization, 59 of them (10.0\%) were oral and maxillofacial surgeons, 46 of them (7.7\%) were pedodontists, 30 of them (5.0\%) were prosthodontists, 25 of them (4.2\%) were orthodontists, 23 of them (3.8\%) were endodontists, 22 of them (3.7\%) were periodontists, 22 of them $(3.7 \%)$ were restorative dentistry specialists and 3 of them $(0.5 \%)$ were oral and maxillofacial radiologists. According to types of clinics, 158 of them (26.7\%) were private practitioners, 151 of them (25.5\%) worked at dental clinics, 141 of them $(23.8 \%)$ worked at university hospitals and 140 of them $(23.7 \%)$ worked at the state dental health centers.

Most dentists $(89.2 \% ; n=521)$ stated that they are not at high risk about COVID-19 (age $>60$ and/or comorbidities including, immunosuppression, respiratory disease, diabetes mellitus, hypertension, cardiovascular disease), while 63 of them (10.7\%) are. The majority of participants $(86.9 \% ; n=508)$ delayed to treat their patients (asymptomatic patients) due to the concerns about COVID-19. Surprisingly, this rate was higher in participants at low risk than participants at high risk (87.5\%; $n=456,82.5 \% ; n=52)$.

\section{COVID-19 knowledge level}

Participants responded that COVID-19 transmitted by aerosol (98.5\%; $n=579)$, saliva $(90.6 \% ; n=533)$, mucosal contact (71.4\%; $n=420)$, blood (36.2\%; $n=213)$, fecal-oral $(32.8 \%$; $\mathrm{n}=193)$ and vertically $(6.6 \% ; \mathrm{n}=39)$.

For the question about clinical symptoms of COVID-19, the most given answer was fever by 587 participants (99.8\%) 
and it was followed by dry cough (99.1\%) fatigue $(90.0 \%)$, sore throat $(84.9 \%)$, diarrhea (64.5\%), nausea and vomiting (56.6\%), headache (54.3\%), dyspnea (46.1\%), myalgia (32\%), sputum formation (29.9\%), arthralgia (21.3\%).

251 participants $(42.9 \%)$ responded the question about the limit for the body temperature defined for COVID-19 to be considered high as $38.5^{\circ} \mathrm{C}$. Other answers were $37.5^{\circ} \mathrm{C}$ by 136 participants $(23.2 \%), 37.7^{\circ} \mathrm{C}$ by 89 participants $(15.2 \%), 37.3^{\circ} \mathrm{C}$ by 86 participants (14.7\%) and $37.1^{\circ} \mathrm{C}$ by 23 participants (3.9\%).

Regarding dental emergency procedures, the majority of population defined acute pulpal pain (94.7\%), severe intraoral bleeding $(90.9 \%)$, tooth fracture with pain $(87.3 \%)$, maxillofacial fracture (80.8\%), alveolar osteitis (74.0\%), severe pericoronitis (73.7\%), abscess $(67.9 \%)$, tooth avulsion $(65.6 \%)$ and breakage of orthodontic wires with soft tissue trauma (63.8\%) as emergency dental situations. However, cementation of fixed dentures (12.6\%), modification of removable prothesis (8.2\%), cementation of implant retained prothesis (6.2\%), asymptomatic tooth fracture (5.8\%), periodic examination and asymptomatic tooth extraction (1.2\%) was also described as emergency dental procedures by respondents.

\section{Attitudes}

Majority of respondents was able to use gloves (96.4\%; $n=558)$, face shield (88.1\%; $n=510)$, disposable gown $(83.4 \%$; $\mathrm{n}=483)$, protective goggles $(73.9 \%, \mathrm{n}=428)$ and disposable coat (20.9\%; $n=121)$ after the WHO declares pandemic.

In procedures which did not generate aerosol, mostly surgical mask with single use $(53.7 \% ; n=311)$ were worn by participants and FFP3/N99 mask with single use $(1.0 \% ; n=6)$ were the least used amongst all mask types. In aerosol-generating procedures, the most used mask type was also surgical mask with single use $(36.0 \% ; n=200)$ and FF1 mask with multiple use (1.6\%; $n=9)$ were the least. In aerosol-generating procedures, FFP2/N95 (33.9\%; $n=189)$ and FFP3/N99 (10.9\%; $\mathrm{n}=61)$ mask usage were higher comparing procedures that did not generate aerosol (FFP2/N95: 12.2\%; $n=71$, FFP3/N99: $5.8 \% ; n=34$ ) However, surgical mask usage was lower in aerosol-generating procedures $(50.7 \% ; n=282)$ comparing other procedures $(77.5 \% ; n=448)$, the differences were highly significant $(p<0.001, p=0.004, p<0.001)$. FFP1 mask usage for both procedures were similar and statistically insignificant $(p=1.00)$. The current values related to mask usage of the participants are presented in Table and Figure 2.

Majority of respondents $(87.0 \% ; n=508)$ stated that they would refer the patients, who presented COVID-19 symptoms, to specials clinics for COVID-19 instead of performing the dental treatment while only 6 respondents (1.0\%) would refer them to university hospitals. 66 respondents $(11.3 \%)$ would prefer to perform only dental emergency procedures, whereas only 4 respondents $(0.7 \%)$ chose to do routine dental treatment. Moreover, regarding asymptomatic patients, more than half of respondents (53.9\%) stated that they would perform only dental emergency procedures.

\section{Anxiety level}

Regarding to evaluation of anxiety of participants, every participants were asked to mark their anxiety level (ranging
Table 1. Mask/respirator usage of the participants in different dental procedures

\begin{tabular}{lcccc}
$\begin{array}{l}\text { Mask/ } \\
\text { respirator } \\
\text { type }\end{array}$ & $\begin{array}{c}\text { Surgical } \\
\text { mask }\end{array}$ & FFP1 & FFP2/N95 & FFP3/N99 \\
\hline $\begin{array}{l}\text { Aerosol- } \\
\text { generating } \\
\text { procedures }\end{array}$ & 282 & 23 & 189 & 61 \\
\hline $\begin{array}{l}\text { Other } \\
\text { procedures }\end{array}$ & 448 & 23 & 71 & 34 \\
\hline $\begin{array}{l}\text { p value }{ }^{*} \\
\text { "Fischer's exact test }\end{array}$ & 1.00 & $\mathrm{p}<0.001$ & 0.004 \\
\hline
\end{tabular}

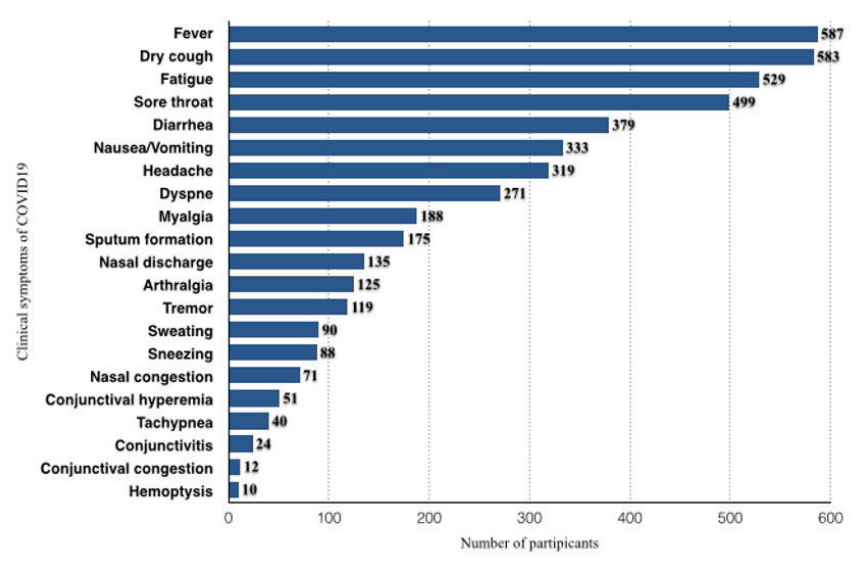

Figure 1. Distribution of responses to 'What are the clinical symptoms of COVID 19?' according to number of participants.

A: Other procedures

B: Aerosol-generating procedures

Multiple use

Single use

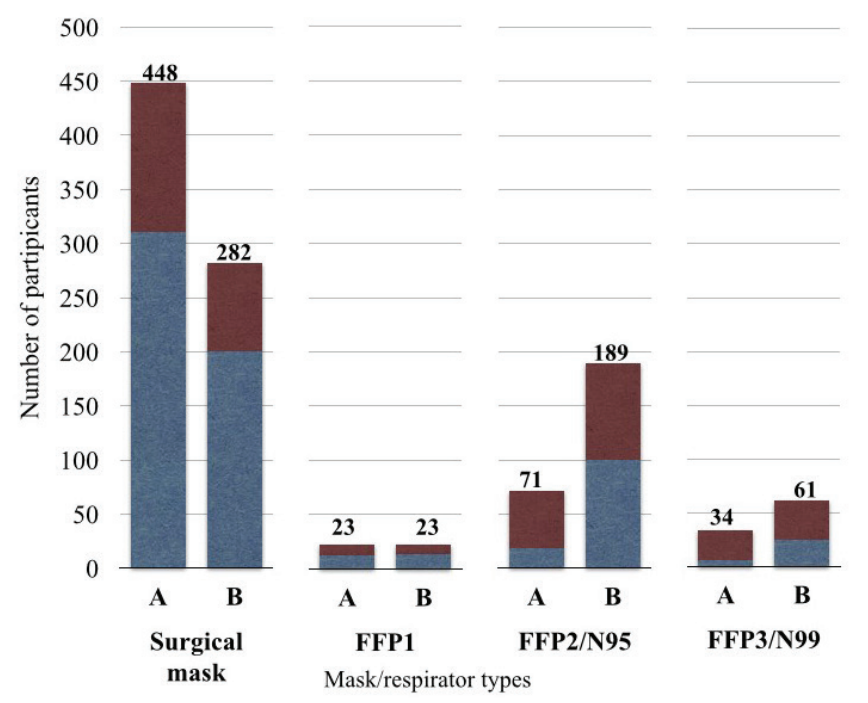

Figure 2. Distribution of responses to 'Which type of mask/respirator do you use in procedures without aerosol (A) and with aerosol (B)?' according to number of participants. 
from 0 to 5) related to pandemic and the mean anxiety level was reported as $3.35 \pm 1.18$. Furthermore, majority of the participants (83.1\%) though that the disease could be transmitted to their selves even by protective equipment and/ or preventions while treating a patient with COVID-19. $16 \%$ of all, stated that protective equipment and/or preventions protects from the transmission of disease, but $0.9 \%$ of the population determined that protective equipment and/or preventions is not required to prevent the disease.

\section{Discussion}

The major outbreak has spread to 210 countries and territories globally and the total number of cases has increased to $2,954,222$ at the time of writing (4). This situation revealed that dentists are at high risk for the transmission of the disease, as it affects all healthcare workers. Furthermore, dental procedures may increase the spread of the disease and it can also be mentioned about the negative effects of public health. In present situation, procedures that dentists should and should not perform became more crucial. Thus, the purpose of this study was to evaluate the knowledge attitudes and anxiety level of dentists about COVID-19.

Age is an important demographic parameter to predict to prognosis of the disease. Arshad et al. (15) study demonstrated that younger people had slower disease progression. These findings coincide with Chinese Center for Disease Control and Prevention (CCDC) which claimed more than $80 \%$ of deaths were seen in people over 60 years old (16). Moreover, comorbidities associated to COVID-19 is also influence the progression of the disease, such as cardiovascular disease, diabetes, hypertension, chronic respiratory disease and cancer (7). In our study, $10.7 \%$ of all participants were stated that they are in high risk group and the majority of this group (\%82.5) postponed to performing treatment because of their concerns about the disease. Although the rates of those in the high risk group seem low in our study, we estimate that the rate among dentists is actually higher. The probable reason that it appeals to younger groups in electronic survey studies, due to the more usage of the internet in these groups.

The possible transmission routes of COVID-19 were previously mentioned in this paper (11-14). The majority of participants responded the way of transmission as microorganism containing aerosol (98.5\%), saliva (90.6\%) and mucosa contact $(71.4 \%)$, respectively. On the other hand, our results also showed poor knowledge of our population about the contamination with blood (36.2\%), fecal-oral (32.8\%) and vertical contamination (6.6\%) routes. The probable reason for the missing information may be that the disease is a newly defined and the mechanism of transmission has not yet been fully described.

As a part of dental procedures, microorganism containing aerosols are generated with high-speed handpieces or ultrasonic devices and these, which are contaminated with saliva and blood, spread and cause long distance contamination (17). Therefore, many authors suggested in order to reduce the transmission potential of this disease, only emergency dental treatments in patients without COVID-19 symptoms are performed in dental clinics (18). Therefore, dentists' knowledge about the protocol and clinical symptoms of the COVID-19 is critical. Most of the participants answered the question about the clinical symptoms of COVID-19 correctly in the presented study. Moreover, the majority of participants $(87 \%)$ responded that a patient who showed symptoms of COVID-19 applied to their clinic, they would refer her/him to special clinics for COVID-19 instead of doing dental treatment.

Rothe et al. (19) reported an asymptomatic case who infected many patients in his incubation period. In addition, Guan et al. (20) have obtained results that the incubation period may be extended up to 19 days which increase the risk of transmission. Besides, atypical symptoms were reported in patients who are highly contagious in another study (21) and they claimed that more than $90 \%$ of patients are not diagnosed correctly. In addition, some authors (22) reported that nucleic acid amplification tests (NAAT) and real-time fluorescence polymerase chain reaction (RT-PCR) tests used in the diagnosis of the disease may even lead to false-negative results in the literature. Hence, every patient should be evaluated as a carrier of the disease and preventive measures should be taken urgently.

The temperature of individuals including staff, patients and their companions should be recorded (23). United States Center for Disease Control and Prevention (US CDC) recommended to defer the treatment when the body temperature is over $38^{\circ} \mathrm{C}(24)$. In contrast, a recent report suggested that the highest limit is $37.3^{\circ} \mathrm{C}$. In our study, only $14.7 \%$ of all participants were answered the highest limit as $37.3^{\circ} \mathrm{C}$ while half of them chose $38.5^{\circ} \mathrm{C}$ (25).

There is no consensus on the selection of masks and respirators (FFP2/N95 or FFP3/N99) in the dental procedures. European Center for Disease Control and Prevention (ECDC) and US CDC recommended respirators for health workers in all procedures, whereas the WHO suggested respirators only in aerosol-generating procedures. Moreover, which respirator will be used in different procedures is also not clear in the literature. ECDC recommended using FFP3 respirators in aerosol-generating procedures, while Public Health England (UK) recommended them for all procedures, for instance $(24,26)$. In the presented study, respirator using was higher in aerosol-generating procedures [FFP2/N95 (33.9\%), FFP3/N99 (10.9\%)] comparing other procedures [FFP2/N95 (12.2\%), FFP3/N99 (5.8\%)]. Unfortunately, the usage of respirators in dental procedures was not enough for proper protection in our study. Some authors (27) recommended using FFP2/N95 or higher respirators for health care workers in all conditions, due to the unclear transmission mechanism of COVID-19. It was confirmed by Wang et al. (28) have also shown a significant decrease in number of infected medical staff with $\mathrm{N} 95$ respirators, although 8.33 times more exposure, compared to no-mask group.

The rapid spread of the disease, the difficulty of its control and the gradually increase in the number of deaths affect the mental health of the health care workers as well as their physical burden. We reported the majority of our respondents think that the protective equipments are not enough to prevent the disease's transmission and the mean anxiety level of the population was 3.35 because of COVID-19. Lai et al. (29) also found similar results which $44.6 \%$ and $71.5 \%$ of 1257 health care workers are showed symptoms of anxiety and depression respectively. 


\section{Conclusion}

The findings of the presented study indicated that variable levels of understanding of COVID-19 and prevention methods among dentists in Turkey. Participants have good knowledge about the emergency dental procedures and disease's transmission routes and symptoms. However, some gaps were observed in respirator usage. Although most of the dental the clinics are closed, dentists continue to perform emergency dental treatments. Hence, dentists should improve their knowledge and attitudes to protect community's and their own health during these challenging times.

Türkçe Özet: COVID-19'da diş hekimlerinin bilgi seviyesi ve davranışı. Amaç: Çalışmanın amacı, diş hekimlerinin COVID-19 ile ilgili olarak bilgi seviyesini, davranışlarını ve kaygı düzeyini değerlendirmektir. Gereç ve Yöntem: Bu kesitsel anket çalışması Türkiye'de görev yapan 590 diş hekimi ile Mart 2020 ile Nisan 2020 tarihleri arasında yapılmıştır. Elektronik anket, katılımcıların demografik bilgileri, COVID-19'un dental yönetimine ilişkin bilgi seviyeleri, klinik uygulamaları ve kaygı düzeyleri ile ilgili 22 soru içermektedir. Anket, katılımcılara elektronik olarak uygulanması amacı ile e-posta ve cep telefonu mesajı ile iletilmiştir. Bulgular: Katılımcıların çoğunluğu aerosol (\% 98,5), tükürük (\% 90,6) ve mukozal teması $(\%$ 71,4) COVID-19'un bulaşma yolları olarak tanımlamıştır. Katılımcıların büyük çoğunluğu ise hastalığın tüm klinik semptomları arasında ateş $(\% 99,8)$, kuru öksürük $(\% 99,1)$ ve halsizliği $(\% 90,0)$ COVID-19 ile ilişkilendirmiştir. Eldiven, katılımcıların \% 96,4'ü tarafindan kişisel koruyucu ekipman olarak kullanılmakta ve bunu siperlik $(\% 88,1)$, tek kullanımlık tulum $(\% 83,4)$ ve koruyucu gözlük (\% $73,9)$ takip etmektedir. Aerosol üretilen işlemlerde FFP2/N95 (\% 33,9) ve FFP3/N99 $(\% 10,9)$ respiratuarların kullanımı aerosol üretilmeyen işlemler ile karşılaştırıldığında daha fazla iken, cerrahi maske kullanımı (\% $50,7)$ daha azdır ve bu farklılık istatistiksel olarak anlamlıdır $(p<0.001$, $p=0.004, p<0.001)$. Katılımcıların ortalama kaygı düzeyi $3.35 \pm 1.18$ (0 ile 5 arasında) olarak tespit edilmiştir. Sonuç: Bu sonuçlar, özellikle COVID-19'un klinik semptomlarında olmak üzere diş hekimlerinin yeterli bilgi düzeyine sahip olduğu göstermektedir. Ancak, aerosol üretilen işlemlerde respiratuar kullanım oranının yetersiz olması diş hekimlerinin pandemi ile ilgili olarak eğitilmesi gerekliliğini göstermektedir. Anahtar Kelimeler: COVID-19, diş hekimliği, maske, respiratuar, davranış

Ethics Committee Approval: The study was approved by Research Ethics Committee of Kocaeli University (Registration number: GOKAEK-2020/5.09 2020/93).

Informed Consent: The informed consents were provided by the participants.

Peer-review: Externally peer-reviewed.

Author contributions: BT and FMC designed the study. BT and FMC participated in generating the data for the study. BT participated in gathering the data for the study. BT and FMC participated in the analysis of the data. FMC wrote the majority of the original draft of the paper. BT and FMC participated in writing the paper. All authors approved the final version of this paper.

Conflict of Interest: The authors had no conflict of interest to declare.

Financial Disclosure: The authors declared that this study has received no financial support.

\section{References}

1. World Health Organization. Novel coronavirus (2019-nCoV), situation report 1, 21 January 2020. https://www.who.int/ docs/default-source/coronaviruse/situation-reports/20200121- sitrep-1-2019-ncov.pdf?sfvrsn=20a99c10_4 Accessed on 2 March 2020.

2. Huang C, Wang Y, Li X, Ren L, Zhao J, Hu Y et al. Clinical features of patients infected with 2019 novel coronavirus in Wuhan, China. Lancet. 2020;395(10223):497-506. [CrossRef]

3. World Health Organization. Naming the coronavirus disease (COVID-19) and the virus that causes it, 12 February 2020. https:// www.who.int/emergencies/diseases/novel-coronavirus-2019/ technical-guidance/naming-the-coronavirus-disease-(covid2019)-and-the-virus-that-causes-it Accessed on 2 March 2020.

4. World Health Organization. Novel coronavirus (2019-nCoV), situation report 99, 28 April 2020. https://www.who.int/docs/ default-source/coronaviruse/situation-reports/20200428sitrep-99-covid-19.pdf?sfvrsn=119fc381_2 Accessed on 29 April 2020.

5. Paules $\mathrm{Cl}$, Marston HD, Fauci AS. Coronavirus infections- more than just the common cold. JAMA 2020;323:707-8. [CrossRef]

6. Zhu N, Zhang D, Wang W, Li X, Yang B, Song J et al. A Novel Coronavirus from Patients with Pneumonia in China, 2019. N Engl J Med 2020;382:727-33. [CrossRef]

7. World Health Organization. Report of the WHO-China Joint Mission on Coronavirus Disease 2019 (COVID-19), 16-24 February 2020. https://www.who.int/publications-detail/ report-of-the-who-china-joint-mission-on-coronavirusdisease-2019-(covid-19) Accessed on 28 February 2020

8. AiT, Yang Z, Hou H, Zhan C, Chen C, LvW et al. Correlation of Chest CT and RT-PCR Testing in Coronavirus Disease 2019 (COVID-19) in China:A Report of 1014 Cases. Radiology 2020; [Epub ahead of print, 2020 Feb 26] Available from: https://pubs.rsna.org/ doi/10.1148/radiol.2020200642?url_ver=Z39.88-2003\&rfr_ id=ori\%3Arid\%3Acrossref.org\&rfr_dat=cr_pub++0pubmed\& [CrossRef]

9. Shi H, Han X, Jiang N, Cao Y, Alwalid O, Gu J et al. Radiological findings from 81 patients with COVID-19 pneumonia in Wuhan, China: a descriptive study. Lancet Infect Dis 2020;20:425-34. [CrossRef]

10. Wang D, Hu B, Hu C, Zhu F, Liu X, Zhang J et al. Clinical Characteristics of 138 Hospitalized Patients With 2019 Novel Coronavirus-Infected Pneumonia in Wuhan, China. JAMA 2020; [Epub ahead of print, 2020 Feb 26] Available from: https:// jamanetwork.com/journals/jama/fullarticle/2761044 [CrossRef]

11. de Wit E, van Doremalen N, Falzarano D, Munster VJ. SARS and MERS: recent insights into emerging coronaviruses. Nat Rev Microbiol 2016;14:523-34. [CrossRef]

12. Wu A, Peng Y, Huang B, Ding X, Wang X, Niu P et al. Genome Composition and Divergence of the Novel Coronavirus (2019nCoV) Originating in China. Cell Host Microbe 2020;27:325-8. [CrossRef]

13. Holshue ML, DeBolt C, Lindquist $S$, Wiesman J, Bruce $H$, Spitters $C$ et al. First Case of 2019 Novel Coronavirus in the United States. N Engl J Med 2020;382:929-36. [CrossRef]

14. Sabino-Silva R, Jardim ACG, Siqueira WL. Coronavirus COVID-19 impacts to dentistry and potential salivary diagnosis. Clin Oral Investig. 2020;24:1619-21. [CrossRef]

15. Arshad Ali S, Baloch M, Ahmed N, Arshad Ali A, lqbal A. The outbreak of Coronavirus Disease 2019 (COVID-19)-An emerging global health threat. J Infect Public Health 2020;13:644-6. [CrossRef]

16. Liu X, Xing B, Xue Z. The Epidemiological Characteristics of an Outbreak of 2019 Novel Coronavirus Diseases (COVID-19) in China (in Chinese). Chinese Journal of Surgery 2020;41:145-51. [CrossRef]

17. Xie $X$, Li Y, Sun H, Liu L. Exhaled droplets due to talking and coughing. J R Soc Interface 2009;6:703-14. [CrossRef]

18. Samaranayake LP, Peiris $M$. Severe acute respiratory syndrome and dentistry: a retrospective view. J Am Dent Assoc 2004;135:1292-302. [CrossRef]

19. Rothe C, Schunk M, Sothmann P, Bretzel G, Froeschl G, Wallrauch C et al. Transmission of 2019-nCoV Infection 
from an Asymptomatic Contact in Germany. N Engl J Med 2020:5;382:970-1. [CrossRef]

20. Bai Y, Yao L, Wei T, Tian F, Jin DY, Chen L et al. Presumed Asymptomatic Carrier Transmission of COVID-19. JAMA 2020;323:1406-7. [CrossRef]

21. Nishiura H, Kobayashi T, Yang Y, Hayashi K, Miyama T, Kinoshita $T$ et al. The Rate of Underascertainment of Novel Coronavirus (2019-nCoV) Infection: Estimation Using Japanese Passengers Data on Evacuation Flights. J Clin Med 2020;9:419. [CrossRef]

22. Dai WC, Zhang HW, Yu J, Xu HJ, Chen H, Luo SP et al. CT Imaging and Differential Diagnosis of COVID-19. Can Assoc Radiol J 2020;71:195-200. [CrossRef]

23. Meng L, Hua F, Bian Z. Coronavirus Disease 2019 (COVID-19): Emerging and Future Challenges for Dental and Oral Medicine. J Dent Res 2020;99:481-7. [CrossRef]

24. Centers for Disease Control and Prevention. Interim Infection Prevention and Control Recommendations for Patients with Suspected or Confirmed Coronavirus Disease 2019 (COVID-19) in Healthcare Settings, 13 April 2020. https://www.cdc.gov/coronavirus/2019ncov/hcp/infection-control recommendations. html?CDC_AA_refVal=https $\% 3 \mathrm{~A} \% 2 \mathrm{~F} \% 2 \mathrm{Fwww} . \mathrm{cdc}$. gov $\% 2$ Fcoronavirus $\% 2$ F 2019 -ncov $\% 2$ Finfectioncontrol\%2Fcontrol-recommend.html Accessed on 18 April 2020

25. Peng X, Xu X, Li Y, Cheng L, Zhou X, Ren B. Transmission routes of $2019-n C o V$ and controls in dental practice. Int J Oral Sci 2020;12:9. [CrossRef]

26. Chughtai AA, Seale H, Islam MS, Owais M, Macintyre CR. Policies on the use of respiratory protection for hospital health workers to protect from coronavirus disease (COVID-19). Int J Nurs Stud 2020;105:103567. [CrossRef]

27. Maclntyre CR, Zhang Y, Chughtai AA, Seale H, Zhang D, Chu Y et al. Cluster randomised controlled trial to examine medical mask use as source control for people with respiratory illness. BMJ Open 2016;6:e012330. [CrossRef]

28. Wang X, Pan Z, Cheng Z. Association between 2019-nCoV transmission and $N 95$ respirator use. J Hosp Infect 2020; [Epub ahead of print, $2020 \mathrm{Mar} 3]$ Available from: https://linkinghub. elsevier.com/retrieve/pii/S0195-6701(20)30097-9 [CrossRef]

29. Lai J, Ma S, Wang Y, Cai Z, Hu J, Wei N et al. Factors Associated With Mental Health Outcomes Among Health Care Workers Exposed to Coronavirus Disease 2019. JAMA Netw Open 2020;3:e203976. [CrossRef] 